\title{
PHENOTYPIC VARIATION OF SOME QUALITATIVE TRAITS IN WEST AFRICAN DWARF GOATS
}

\author{
Fajemilehin, S.O.K ${ }^{* 1} \rrbracket$, M.K. Adegun ${ }^{2}$ \\ ${ }^{*} 1,2$ Department of Animal Science, Faculty of Agricultural Sciences, Ekiti State University, Ado \\ Ekiti, Nigeria
}

D0I: https://doi.org/10.29121/granthaalayah.v8.i5.2020.83

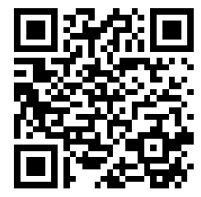

Article Type: Research Article

Article Citation: Fajemilehin, S.O.K. and M.K. Adegun. (2020).

PHENOTYPIC VARIATION OF SOME QUALITATIVE TRAITS IN WEST AFRICAN DWARF GOATS. International Journal of Research GRANTHAALAYAH, 8(5), 94-99. https://doi.org/10.29121/granthaa layah.v8.i5.2020.83

Received Date: 13 May 2020

Accepted Date: 28 May 2020

Keywords:

Beard

Colour Pigmentation

Horned

Qualitative Traits

Wattle

West African Dwarf Goats

\section{ABSTRACT}

Each class of livestock has some peculiar qualitative traits and in goats some of these are coat pigmentation, horned/polled, beard/non-beard, wattled/non-wattled. Since the impact of environment is important in phenotypic expression of qualitative traits, it becomes expedient to examine these features in West African Dwarf Goats (WADG) from every climatic region of the world. To accomplish this, a total of 623 WADGs aged between 3 and 4 years reared extensively in Ekiti state region of Nigeria were purposively selected from the three agricultural zones in the state for the examination. Data were collected on coat pigmentation, horns, wattle and beard on sex basis. The commonest pigmentation was black at $31.29 \%$, $35.43 \%$ and $34.18 \%$ in the three zones and the least encountered was mixed pigmentation at $11.66 \%, 07.62 \%$ and $08.44 \%$ respectively. The number without wattles (57\%) outnumbered those with wattles $(43 \%)$. $88 \%$ had no beards and $87 \%$ were horned. $30 \%$ of does had wattles and $59 \%$ were horned as against $13 \%$ and $29 \%$, respectively in bucks. In all, $2 \%$ of doe and $9 \%$ of buck had beards. The levels of variation in the traits surveyed in the three Districts indicated that WADGs in the region are predominantly black, not wattled, not bearded and horned.

\section{INTRODUCTION}

In nature, the influence of the environment forms the basis of natural selection, favouring the survival of the best-suited phenotypes to that environment. The survival advantage of individuals exhibiting such phenotypes enables those individuals to reproduce with relatively high rates of success and thereby pass on the successful genotypes to subsequent generations. These phenotypic traits could be categorically discerned and are measurable (qualitative) or vary continuously resulting from the interactions of genotype with the environment (quantitative).

Each class of livestock has some peculiar qualitative traits and in goats some of these are coat colour, horned or polled, beard or non-beard, wattled or non-wattled. [1] reported that all Creole goats, both pure and crossbred, were horned and $62 \%$ of pure breed and $100 \%$ of their crosses are bearded. Almost all indigenous Hararghe highland Goat breed has no wattle (95.9\%) and 78.1\% were without beards [2][3] reported that qualitative traits displayed by WAD goats include wattles which could appear bilaterally, unilaterally or absent with frequency distributions of about $63 \%, 6 \%$ and $31 \%$, respectively. They reported that the possession of beard is common among all breeding males (88\%) and about $12 \%$ of breeding does. [4] mapped the dominant caprine wattles (W) locus in 341 goats from

(C) 2020 The Author(s). This is an open access article distributed under the terms of the Creative Commons Attribution License, which permits unrestricted use, distribution, and reproduction in any medium, provided the original author and source are credited. 
nine different Swiss goat breeds and found that $51.02 \%$ of the goats examined have wattles while $48.98 \%$ were without wattles.

The opinions on the usefulness of some of these traits particularly wattles vary. [5] reported the impact of wattle on heat tolerance among West African dwarf goats, but some breeders consider them to be of little or no use. [6] at http/www.dairy journal.com believed wattles to be a genetic trait "left over" from evolution. However, it is possible that the presence in some goats over the years of evolution could not have been accidental but an indication that the reasons for their presence are still not understood.

These traits have not been studied in Ekiti State region of Nigeria and since the impact of environment is important in phenotypic expression of traits, it becomes expedient to examine these features in WAD goats of this region to know how closely related/unrelated they are with goats of the same breed from other regions.

\section{MATERIALS AND METHODS}

The study was carried out in Ekiti State situated entirely within the tropics. It is located between longitudes $40^{\circ} 51^{\prime}$ and $50^{\circ} 451^{\prime}$ east of the Greenwich meridian and latitudes $70^{\circ} 151^{\prime}$ and $80^{\circ} 511^{\prime}$ north of the Equator. It lies south of Kwara and Kogi States, East of Osun State and bounded by Ondo State in the East and in the south. The State enjoys a tropical climate with two distinct seasons. These are the rainy season (April - October) and the dry season (November - March). Temperature ranges between $21^{\circ} \mathrm{C}$ and $28^{\circ} \mathrm{C}$ with high humidity. The south - westerly winds and the North East Trade winds blow in the raining and dry (Harmattan) seasons, respectively. Tropical Forest exists in the south, while guinea savanna predominates in the northern peripheries.

There are 16 Local Government Areas (LGAs) in the state under 3 Agricultural zones: Ekiti South (Agricultural zone A), Ekiti Central (Agricultural zone B) and Ekiti North (Agricultural zone C). Agricultural zone A is made up of six LGAs: Ekiti East, Aiyekire, Ekiti South West, Ikere, Ise-Orun and Emure; Agricultural zone B is made up of five LGAs: Ado, Irepodun/Ifelodun, Ekiti West, Efon Alaaye and Ijero while Agricultural zone C is made up of five LGAs: Ikole, Oye, Ilejemeje, Moba and Ido-osi.

\subsection{EXPERIMENTAL ANIMALS AND SAMPLING TECHNIQUE}

A total of 623 adult WAD goats aged between 3 and 4 years and comprising of 163 from Agricultural zone A, 223 from Agricultural zone B and 237 from Agricultural zone extensively reared were selected purposively for the examination. The ages of the goats were estimated from the number of teeth that have erupted according to [7]. The local government areas in each Zone were arranged alphabetically and thereafter numbered serially. All the local government areas that are even-numbered were selected as experimental sites. In all, a total of seven local government areas were selected for the study. The LGAs were Ekiti East, Emure and Ise-Orun in Agricultural zone A; Efon-Alaaye and Ijero in Agricultural zone B and Ikole and Moba in Agricultural zone C.

\subsection{DATA COLLECTION}

Data were collected on qualitative traits (coat colour pigmentation, horns, wattle and beard). The coat colour pattern described by [8] was used as guideline.

\subsection{DATA ANALYSIS}

Phenotypic frequency was computed by direct count. The proportion (\%) of individuals carrying the various traits was determined using the formula:

$$
\text { Phenotypic frequency }=\frac{\text { Number of individual animals having the trait }}{\text { Total number of animals sampled }} \times 100
$$

Data on sex was analyzed using descriptive statistics to determine the effect of sex and the means were separated using Student t-test according to [9] 


\section{RESULTS AND DISCUSSIONS}

The coat pigmentation pattern in WAD goats of Ekiti state is presented in Table 1. The different pigments observed in the three districts were black/dark, dark brown, light brown, mixed colour and white. The commonest pigment was black at 31.29\%, 35.43\% and 34.18\% in Agricultural zones A, B and C respectively and the least encountered was mixed colour at $11.66 \%, 07.62 \%$ and $08.44 \%$. The results showed that black or dark coat pigmentation is predominant in Ekiti State as observed by [10] and [3] in West African Dwarf goats in Southern Nigeria. Coat pigmentation is dependent on melanin concentration, the darker the colour the higher the melanin concentration. Melanin is important in mammalian pigmentation [11]because it has the capacity to dissipate over 99.9\% of absorbed UV radiation [12] and acts as a mat to physically prevent the sun rays from reaching the animal's body [13]. The preponderance of black pigmentation trait in this study therefore could be regarded as an adaptive feature developed for survival in the ecological zone. The phenotypic frequency of wattle in WAD goats of Ekiti State is presented in Table 2. The number of goats without wattles (57\%) in this study outnumbered those with wattles (43\%) which is lower than 95.9\% in indigenous Hararghe highland Goat breed [2] and 69\% in WAD goats [3]. The result disagrees with [4] who noted that wattled goats outnumbered the non-wattled in nine different Swiss goat breeds. Therefore, the submissions of [5] and [14] that wattle possession in goats could have thermoregulatory functions is contentious. However, an assortative mating of individuals with or without wattle could reveal the reproductive advantage/ disadvantage of the trait.

Table 1: Coat pigmentation pattern of WAD goats

\begin{tabular}{|c|c|c|c|c|c|c|}
\hline Colour & \multicolumn{2}{|c|}{ Agricultural zone A } & \multicolumn{2}{c|}{ Agricultural zone B } & \multicolumn{2}{c|}{ Agricultural zone C } \\
\hline Colour pattern & Number & Frequency (\%) & Number & Frequency (\%) & Number & Frequency (\%) \\
\hline Black/Dark & 51 & 31.29 & 79 & 35.43 & 81 & 34.18 \\
\hline Dark brown & 35 & 21.47 & 50 & 22.42 & 53 & 22.36 \\
\hline Light brown & 27 & 16.56 & 34 & 15.25 & 37 & 15.61 \\
\hline Mixed colour & 19 & 11.66 & 17 & 07.62 & 20 & 08.44 \\
\hline White & 31 & 19.02 & 43 & 19.28 & 46 & 19.41 \\
\hline Total & 163 & 100 & 223 & 100 & 237 & 100 \\
\hline
\end{tabular}

Table 2: Phenotypic frequency of wattle in WAD goats of Ekiti State

\begin{tabular}{|c|c|c|c|}
\hline & Genotype & Number of obs. & Observed Phenotypic frequency \\
\hline Agricultural zone A & $\mathrm{Wa}^{+}$ & 39 & 0.24 \\
& $\mathrm{Wa}^{\mathrm{w}}$ & 124 & 0.76 \\
Total & & $\mathbf{1 6 3}$ & $\mathbf{1 . 0 0}$ \\
\hline Agricultural zone B & $\mathrm{Wa}^{+}$ & 144 & 0.65 \\
& $\mathrm{Wa}^{\mathrm{w}}$ & 79 & 0.35 \\
Total & & $\mathbf{2 2 3}$ & $\mathbf{1 . 0 0}$ \\
\hline Agricultural zone C & $\mathrm{Wa}^{+}$ & 83 & 0.35 \\
& $\mathrm{Wa}^{w}$ & 154 & 0.65 \\
Total & & $\mathbf{2 3 7}$ & $\mathbf{1 . 0 0}$ \\
\hline & $\mathrm{Wa}^{+}$ & 266 & 0.43 \\
G/Total & $\mathrm{Wa}^{w}$ & 357 & 0.57 \\
\hline
\end{tabular}

The phenotypic frequency of beards in WAD goats is presented in Table 3 . In this study, $88 \%$ of the goats do not possess beard which is higher than $78.1 \%$ observed in indigenous Hararghe highland Goat breed by [2]. The result however disagrees with the observation that $62 \%$ of Creole goats' pure breed and $100 \%$ of their crosses possess beards [1]). The result suggests that possession of beards is not a frequent characteristic of WAD goats in the study area. Table 4 showed the phenotypic frequency of horns in WAD goats. The result revealed that $87 \%$ of the goats were horned while $13 \%$ were polled. The result agrees with the report in http://nigerian dwarfcolors.weebly.com/polledhorned-genetics.html that most Nigerian Dwarf goats are born with horns. The sex effect on the phenotypic traits in WAD goats are as shown in Table 5. The parameters studied revealed sexual 
dimorphism. Possession of wattle and horn were more prominent in the female goats being 30\% and 59\%, respectively as against $13 \%$ and $29 \%$, respectively in male. In all, $2 \%$ of female and $9 \%$ of male possess beard.

Table 3: Phenotypic frequency of beard in WAD goats of Ekiti State

\begin{tabular}{|c|c|c|c|}
\hline & Genotype & Number of obs. & Calculated Phenotypic frequency \\
\hline $\begin{array}{c}\text { Agricultural zone A } \\
\text { Total }\end{array}$ & $\begin{array}{l}\mathrm{Br}^{+} \\
\mathrm{Br}^{-}\end{array}$ & $\begin{array}{c}64 \\
99 \\
163\end{array}$ & $\begin{array}{l}0.39 \\
0.61 \\
\mathbf{1 . 0 0}\end{array}$ \\
\hline $\begin{array}{c}\text { Agricultural zone B } \\
\text { Total } \\
\end{array}$ & $\begin{array}{l}\mathrm{Br}^{+} \\
\mathrm{Br}^{-}\end{array}$ & $\begin{array}{c}11 \\
212 \\
223 \\
\end{array}$ & $\begin{array}{l}0.05 \\
0.95 \\
\mathbf{1 . 0 0} \\
\end{array}$ \\
\hline $\begin{array}{c}\text { Agricultural zone C } \\
\text { Total } \\
\end{array}$ & $\begin{array}{l}\mathrm{Br}^{+} \\
\mathrm{Br}^{-}\end{array}$ & $\begin{array}{c}00 \\
237 \\
237\end{array}$ & $\begin{array}{l}0.00 \\
1.00 \\
\mathbf{1 . 0 0}\end{array}$ \\
\hline Overall Total & $\begin{array}{l}\mathrm{Br}^{+} \\
\mathrm{Br}^{-}\end{array}$ & $\begin{array}{c}75 \\
548 \\
623\end{array}$ & $\begin{array}{l}0.12 \\
0.88 \\
\mathbf{1 . 0 0}\end{array}$ \\
\hline
\end{tabular}

Table 4: Phenotypic frequency of horn in WAD goats

\begin{tabular}{|c|c|c|c|}
\hline & Genotype & Number of obs. & Observed phenotypic frequency \\
\hline Agricultural zone A & $\mathrm{Ho}^{+}$ & 143 & 0.88 \\
\hline & $\mathrm{Ho}^{\mathrm{p}}$ & 020 & 0.12 \\
\hline Total & & 163 & 1.00 \\
\hline Agricultural zone B & $\mathrm{Ho}^{+}$ & 174 & 0.78 \\
\hline & $\mathrm{Ho}^{\mathrm{p}}$ & 049 & 0.22 \\
\hline Total & & 223 & 1.00 \\
\hline Agricultural zone $\mathrm{C}$ & $\mathrm{Ho}^{+}$ & 228 & 0.96 \\
\hline & $\mathrm{Ho}^{\mathrm{p}}$ & 009 & 0.04 \\
\hline Total & & 237 & 1.00 \\
\hline Total & $\mathrm{Ho}^{+}$ & 545 & 0.87 \\
\hline & $\mathrm{Ho}^{p}$ & 78 & 0.13 \\
\hline Overall total & & 623 & 1.00 \\
\hline
\end{tabular}

The result disagrees with the report of [3] that possession of beard is common among all breeding males (88\%) and about $12 \%$ of breeding does.

Table 5: Sex effect on some phenotypic traits in WAD goats of Ekiti State

\begin{tabular}{|c|c|c|c|}
\hline Traits & Genotype & Number of obs. & Observed phenotypic frequency \\
\hline Wattle & \multicolumn{3}{|l|}{} \\
\hline Female & Wa+ & $188 \mathrm{a}$ & 0.30 \\
Male & Wa+ & $79 \mathrm{~b}$ & 0.33 \\
Female & Waw & $208 \mathrm{a}$ & 0.13 \\
Male & Waw & $148 \mathrm{~b}$ & 0.24 \\
\hline Beard & \multicolumn{3}{|}{} \\
\hline Female & $\mathrm{Br}+$ & $15 \mathrm{~b}$ & 0.02 \\
Male & $\mathrm{Br}+$ & $59 \mathrm{a}$ & 0.61 \\
Female & $\mathrm{Br}-$ & $381 \mathrm{a}$ & 0.09 \\
Male & $\mathrm{Br}-$ & $168 \mathrm{~b}$ & 0.28 \\
\hline Horn & \multicolumn{3}{|}{} \\
\hline
\end{tabular}




\begin{tabular}{|c|c|c|c|}
\hline Female & Ho+ & $366 \mathrm{a}$ & 0.59 \\
Male & Ho+ & $183 \mathrm{~b}$ & 0.05 \\
Female & Hop & $30 \mathrm{~b}$ & 0.29 \\
Male & Hop & $44 \mathrm{a}$ & 0.07 \\
\hline \multicolumn{2}{|l}{ a,b means with different superscripts deferred $(\mathrm{p}<0.05)$} \\
\hline
\end{tabular}

\section{CONCLUSION}

The levels of variation in the traits surveyed in the three zones indicated that the coat pigmentation of WAD goat in Ekiti State is predominantly black; $57 \%$ of them were not wattled; $88 \%$ were not bearded while $87 \%$ of them were horned.

\section{RECOMMENDATION}

The usefulness of each of the traits should be assessed through controlled experiments and modes of inheritance determined by selective crossbreeding.

\section{SOURCES OF FUNDING}

None.

\section{CONFLICT OF INTEREST}

None.

\section{ACKNOWLEDGMENT}

People who contributed to the work but do not fit criteria for authorship should be listed in the Acknowledgments, along with their contributions. It is advised that authors ensure that anyone named in the acknowledgments agrees to being so named. Funding sources that have supported the work should also be cited.

\section{REFERENCES}

[1] Edilberto, C; Fernando, M.; Francisco, V.; Samuel, RP.; Eliecer, P. and Concepta, M. (2011). Morphological measurements and body indices for cuban creole goats and their crossbreds. R. Bras. Zootec. 40 : 8. Http://dx.doi.org /10 1590/ s1516-35982011000800007

[2] Dereje Tsegaye, Berhanu Belay and Aynalem Haile (2013). Morphological Characterization of Indigenous Hararghe Highland Goat Breed in Their Native Environment, West Hararghe, Ethiopia. American-Eurasian Journal of Scientific Research 8 (2): 72-79.

[3] Oseni, SO. and BA. Ajayi (2014). Phenotypic Characterization and Strategies for Genetic Improvement of WAD Goats under Backyard Systems. Open Journal of Animal Sciences. Vol.04 No.05, Article ID:50125, 9 pages

[4] Reber, I. ; Keller, I.; Becker, D.; Flury, C.; Welle, M. and Drögemüller C. (2015). Wattles in goats are associated with the FMN1/GREM1 region on chromosome 10. Anim Genet.46(3):316- 20. doi: 10.1111/age.12279.

[5] Adedeji, TA (2012). Effect of Some Qualitative Traits and Non-Genetic Factors on Heat Tolerance Attributes of Extensively Reared West African Dwarf (WAD) Goats. International Journal of Applied Agricultural and Apicultural Research. 8 (1): 68-81

[6] Stultz (2015). http/www.dairy journal.com. Accessed on July, 2019.

[7] Gerald, W (1994). The Tropical Agriculturalist Macmillan Press Ltd. London, pp. 54-57.

[8] Kolo, PS.; SSA. Egena; DN Tsado and M. Adisa-Shehu (2015). Phenotypic and genetic categorization of qualitative traits in extensively managed local goat (Capra aegagrus) population of Niger State, Nigeria. Nigerian Journal of Genetics. 1-6. Available online at www.sciencedirect.com 
[9] Rosner, B. (1995). Fundamentals of Biostatistics, $4^{\text {th }}$ ed., Wadsworth Publishing Co., Belmont, California.

[10] Adedeji, TA., LO. Ojedapo, OS. Adedeji, TA. Aderogba and AR. Abdullah. (2006) Characteristics of traditionally reared West African Dwarf Goats (WAD) in the Derived Savannah Zone of Nigeria. Journal of Animal and Veterinary Advances. 5 (8): 686-688.

[11] Jimbow, K; Quevedo WC, Jr; Fitzpatrick, TB; Szabo, G (1976). "Some aspects of melanin biology: 1950-1975". The Journal of Investigative Dermatology. 67 (1): 72-89.

[12] Meredith P and Riesz J (2004). "Radiative relaxation quantum yields for synthetic eumelanin". Photochemistry and Photobiology. 79 (2): 211-6.

[13] Baton R, Louisiana SV and Roussel JD (2004). Heat Stress. In: National Goat Hand book. National Agriculture Database Laboratory. http. // outlands. tripod. com/ farm / national- goat- handbook.

[14] Odubote, IK. (1994). Characterization of the West African Dwarf Goats for certain qualitative traits. Nigerian Journal of Animal Production. 21:37-41. 